\title{
Systematically Employing a Trinity of User-Friendly Vocabulary Assessment Tools
}

\author{
John Paul Loucky \\ Seinan Women's University
}

\begin{abstract}
When surveying many texts and research articles on the teaching of vocabulary, what often seems to be missing is a clear and systematically elaborated taxonomy of essential strategies for lexical acquisition based on findings in applied linguistics and learning theory. Teachers are left wondering how to help language learners build up a large TL vocabulary quickly, especially those who intend to do further academic or technical study and work in English. Since building learners' understanding of word meanings is so crucial to any other language development, the following reason-and research-based taxonomy is recommended to help teach students how to more systematically and successfully process new target language (TL) vocabulary. A "Depth of Lexical Processing Grid or Taxonomy" is proposed, which relates to both common, essential vocabulary learning strategies and logical steps for cognitively processing and storing new words. Having a practical and user-friendly Depth of Lexical Processing Taxonomy available can help both language instructors and learners to better monitor their vocabulary development, so that they can be given more specific vocabulary learning strategies (VLS) instruction and practice in crucial but off-neglected areas.

Can the complex and various facets of second language vocabulary learning actually be measured with instruments that are user-friendly, and which can be made understandable to students and teachers alike? This article proposes several evaluative and instructional tools and ways in which both L1 and L2 vocabulary assessment and instruction can be made more accessible and understandable by using them within a simple, yet all-encompassing model of second language vocabulary acquisition (SLVA).
\end{abstract}

1. Introduction: "Does vocabulary come naturally or must it be taught and learned? If so, what are the aspects of vocabulaty that are amenable to instruction and study?" These key questions raised by Ellis (1995:1) have been echoed repeatedly in various debates and studies about first and second language vocabulary acquisition. The guiding assumption of this overview of essential aspects of vocabulary acquisition is that language learning seems to have four major aspects, each of which need to be taught and assessed separately in order to understand these processes more fully. In addition, a systematic plan based on these clarifications can help improve and integrate both vocabulary instruction and study, if its insights are adequately appreciated and applied. These four major processes of language and vocabulary learning are 1) Discovery or Recognition of new or repeated information about word forms or meanings, 2) Consolidation or Integration, 3) Prediction, and 4) Production (Author, 1996). In simpler terms, vocabulary learning strategies can be divided into these first two types, as Schmitt (1997) has done, although prediction should be encouraged in guessing unknown word meanings, as well as when trying to predict appropriate words, structures and meanings as one is attempting to decode and comprehend any text. A useful metacognitive map of most essential phases of lexical processing is given in the following Depth of Lexical Processing Scale (shown in Table 1), whose recycling taxonomy was designed to help better assess both visible and hidden vocabulary learning behaviours. 
Questions of user-friendliness have always been important to consider for improving the sales of any computer equipment, but is a much more important factor to consider when making or using $\mathrm{E}$ Learning materials, especially those intended for language use. Such materials must be as transparent, intuitive and as easy to use as possible for learners of limited language proficiency. Similarly tools for guiding and assessing learner's study of a second or foreign language vocabulary need to be much more comprehensible, so that both learners and teachers can make more effective use of them to guide their study and instruction respectively. This article recommends three instruments designed for such ease of use.

\section{Using a Trinity of Tools for Improving Vocabulary Teaching \& Testing}

Just as there are three states of matter, solid, liquid and gas-so too there also seem to be three major dimensions of vocabulary knowledge. These three aspects are 1) Vocabulary Size-also known as Breadth of one's word knowledge, or Quantity of words known in a particular language, or specific field of knowledge; 2) Vocabulary Depth-also known as Richness or Quality of knowledge about particular words or phrases; and 3) Degree of Organization-meaning how well structured one's vocabulary knowledge is.

Several instruments designed by the author are used to measure each of these aspects of vocabulary knowledge in order to better assess each of these areas. By using several such instruments as well as personal interviews and observation of students' dictionary usage skills and world learning strategies, as well as by inspection of their personal Vocabulary Notebooks or Language Learning Journals one can do a kind of triangulation or get an assessment of a learner's vocabulary knowledge from three angles or dimensions, as a surveyor would do when measuring a piece of land or property before sale.

Although many foreign language learners appear to use only a limited number of language and lexical learning strategies; as do most of the Japanese college students surveyed in this study, teachers who want to be more effective are looking for some system that can combine as many proven strategies, good ideas and resources as possible to help their students to more quickly improve their vocabulary, reading comprehension, and language leaming skills. Segler, Pain, and Sorace (2001) surveyed strategy types and training for typical classrooms, seeking ways to use ICALL environments to better enhance second language vocabulary acquisition. Vocabulary learning strategies (or VLS) are a crucial sub-class of 
general language learning strategies, as they concluded, seeing little work done yet in the area of VLS

taxonomy development, other than that of Stoffer (1995), Schmitt (1997), and Kudo (1999). They state:

The importance of VLS in the group of language learning strategies is reflected by the fact that the vast majority of strategies in taxonomies such as Oxford's are either VLS (all strategies in the memory category), or can be used for vocabulary learning tasks. Although the use of a wide variety of strategies has been found to be characteristic for [sic] successful learners, the great majority of learners seem to favour some form of mechanical strategy such as repetition over deeper, more complex ones, such as contextual guessing or metacognitive strategies (Lawson \& Hogben, 1996; Gu \& Johnson, 1996). This finding is disappointing in the light of the Depth-ofProcessing (DOP) hypothesis (Craik \& Lockhart, 1972), which states that 'deeper' analysis of a stimulus (with 'depth' referring to a greater degree of semantic involvement [or elaboration]) leads to better long-term memory retention. (Segler, Pain, and Sorace, 2001, p. 2)

\section{Depth of Lexical Processing Scale or Taxonomy}

To help meet this very real need of language teachers, learners and researchers, to further test this "Depth of Processing Hypothesis," and to further develop this yet limited field of VLS taxonomies, the following study was done. Based on as full a review of this area as is possible in a limited journal article, incorporating known principles of foreign language vocabulary learning, and based on surveys of actual Japanese EFL students' VLS preference and use, the following Depth of Lexical Processing Scale is proposed to help both instruct and assess students in the use of a logical and systematic approach to leaming new words and phrases.

Indeed Waring (2002, p. 16) is correct in asserting that "if we are to construct vocabulary knowledge scales of any kind, then we should do so with a particular framework in mind." The "Vocabulary Learning Taxonomy" viewed within the defining parameters of a "Depth of Lexical Processing Scale" or grid given below is the framework in the mind of this researcher. It is based on increasing evidence being accumulated from research reviews, student VLS surveys and interviews, and classroom instruction indicating that lexical development occurrs at various phases of a recycling (or reiterative) continumm Such a scale represents the process of SLVA in which different aspects of word knowledge are being developed, at times simultaneously but sometimes separately. Such a cyclical model of second language lexical processing and learning could help to improve EFL vocabulary research by generating a more accurate picture of actual L2 lexical development. In addition, it could give both language instructors and learners a better guide for monitoring their degree of vocabulary organization, known to be a key factor in becoming a more successful and proficient language learner. 
As Read (2000, p. 28) notes, "For general proficiency purposes, Meara favours the second approach [making an overall assessment of the state of a learner's vocabulary, rather than just testing how well certain words are known] and proposes two key measures: an estimate of vocabulary size and a measure of how well organized the learner's vocabulary knowledge is." Having a practical and userfriendly Depth of Lexical Processing Taxonomy available can help both language instructors and learners to better monitor their vocabulary development, so that they can be given more specific vocabulary learning strategies (VLS) instruction and practice in weak or neglected areas.

Lest we misrepresent the nature of $L 2$ lexicon development, each aspect of lexical development needs to be studied and analyzed more carefully, combining the use of various assessment instruments which can help us get better views of the mind and mental lexicons of language learners in the daunting task of foreign language vocabulary acquisition. Lexical development may be viewed as a series of cyclical phases requiring continuous assessment, rather than a simple linear process without need of recycling or repetition. While vocabulary knowledge is seen by some as being on a simple linear scale of steps, lexis appears to develop along a multi-layering continuum (meaning a series of closely connected characteristics, events, phases, aspects or dimensions) as "memory traces" (imprints and re-imprints) are gradually built up over time. Productive activation is certainly an often neglected step, especially among foreign language learners without the benefit of much TL exposure, which is an important phase of lexical acquisition found in the taxonomy proposed below.

\section{A Proposed Overall Model for Assessing Vocabulary Teaching and Testing}

Using a Depth of Lexical Processing Scale or Taxonomy (Author, 2003d, 2005a)

\section{Discovery Phase Processes-}

1) Attending to and Assessing levels of vocabulary knowledge-(e.g, by using a scale);

2) Accessing new word meanings and forms or patterns of use (by guessing, asking/dictionary);

3) Archiving new information-(physically recording or making a mental note);

4) Anchoring it even short-term within Audio-Visual and Episodic memory fields; and

\section{Consolidation Phases-}


5) Associating-Organizing or Structuring new TL terms and concepts within the L1 or L2 mental lexicon by integrating them within known semantic associative networks/domains/ fields/schemata;

6) Analyzing the various word parts and aspects of new vocabulary knowledge;

7) Reassessing vocabulary learning (using post-checks, VKS, self-monitoring, etc.);

8) Re-meeting/Re-encountering missed words to Relearn them by Reactivation;

III. Building Predictive Skills, or Developing of one's Anticipatory Set-

9) Automatically recognizing fully acquired or thoroughly learned TL vocabulary;

10) Learning to Anticipate and Predict appropriate places to find or use new TL terms;

IV. Elaborating or Extending Productive Phases of Lexical Development--

11) Activating new target language via generative productive use;

12) Recycling/Reviewing/Reactivating TL vocabulary;

As Meara (2002) has recently written, good texts on vocabulary teaching and learning are both basically practical as well as research-based. Taking the unifying principles that bind Nation's recent book (2001) in this category as the springboard for launching our discussion, let us look at how it defines both the teaching and research tasks. Nation's four practical unifying principles noted by Meara (2002: 395) are that vocabulary needs to be systematically integrated into any course, in these four ways:

1) By giving learners meaning-focused comprehensible input, 2) By giving learners direct and explicit vocabulary instruction, and not relying solely on informal, incidental exposure as being sufficient for their needs, 3) By requiring learners to engage in language production activities, and 4) Only by building increasingly higher levels of complexity and fluency can one gain near-native control of a target language. Read (2000) agrees that one must start by specifying the various components of lexical knowledge and then "propose what the key variables are" (p. 36), as Chapelle (1994) has done.

Nation $(1990 ; 1994 ; 2001)$ has painstakingly collated much useful research on SLVA, and clarified formal measures to operationalize the most important concepts thereof. Among these are "tools for measuring the complexity and comprehensibility of text [Nation \& Newton, 1997], tools for assessing the extent of learners' vocabulary, standardized word lists [Nation, 1990, Appendices Headword Level Lists and Tests], and so on" (Meara, 2002: 396). Yet it remains a daunting challenge to disambiguate the 
various aspects involved in L1 versus L2 vocabulary acquisition, and to provide a clearer model thereof to help language teachers and students to teach and learn more effectively. This work is a cautious attempt to build up such a model, based on original research with Japanese college EFL students and an overview of major works that have contributed to our understanding of this field.

Although we evaluate writing by its quality rather than by one's quantity of words, the vocabulary knowledge of foreign language learners as well as of natives needs to be evaluated from both perspectives. As in most fields of knowledge, one's degree of learning depends not merely on the amount of study hours spent, but rather upon its quality or how well that time has been invested. So too a language learner's degree of vocabulary acquisition depends mostly on their degree of exposure to target language, and on the quality of their subsequent organization, study and use thereof. Because one can reasonably expect that $\mathrm{L} 2$ learning patterns most likely parallel a learner's patterns of $\mathrm{Ll}$ vocabulary study, organization and use, and many such language processing skills are known to transfer, each individual learner's patterns of L1 and L2 vocabulary learning should be more thoroughly studied and compared. While these are fairly simple and straightforward concepts to understand, designing more effective means of researching, teaching and testing the various important aspects of foreign language vocabulary has been both problematic and challenging in many ways.

A good scientific model is both simple and yet profound, clarifying many complex relationships while also helping to generate many useful hypotheses for further research testing as well as more effective applications. This brief overview of the major aspects involved in vocabulary teaching and testing serves to draw together many strands of research into a user friendly and testable model, which seeks to clarify various types and aspects of vocabulary as well as various kinds of tests that may be most appropriate for assessing and analyzing each of these interrelated areas of lexical development. In particular, a trinity of lexical assessment measures devised by the author are incorporated into this model (see in Table 1), showing how one researcher or teacher might try to both assess and instruct students in each of these major areas of lexical development.

Chapelle's (1994) three-fold view of vocabulary development includes these main components, as shown in Table 1: 1) a theory of context, 2) a framework for vocabulary ability, and 3) metacognitive 
strategies for vocabulary learning, study and review. Three basic instruments have been designed by this writer to help measure each of the three major aspects of vocabulary learning, namely

A. DAVIE VKS can give a partial view of the quality of learner's L1 translation ability, $\mathrm{L} 2$ defining ability, L2 collocational knowledge and L2 semantic and syntactical sentence use (Author, 2003a, 2004b). Size/ breadth/quantity of $L 2$ vocabulary is measured, but quality can be evaluated in those sentences that are generated as well.

B. A Depth of Lexical Processing Scale - that both guides and measures each major stage of vocabulary development (Author, 2003d, 2005a). Quality and degree of VLS structure and study habits as well as type and pattern of VLS used can be readily shown, taught, learned and assessed.

C. Vocabulary Learning Strategies Taxonomy (based on Schmitt, 1997)--Organized into a 40-Item Checklist These show basic observable physical and/social learning behaviors.

Examining a learner's mental lexicon storage structure and the relative strength of their ability to order new terms and make correct associations among both L1 and L2 terms can reveal not only many aspects of that individual's internal lexical organization. In addition, learners' frequently used or preferred metacognitive lexical processing strategies may be revealed, such as conscious planned structures or routines for recording and structuring one's L2 lexicon, both physically and mentally. Due to limitations of space, separate studies using each of these instruments can only be alluded to briefly here, with an overview of major results of their classroom use being presented, showing how such a systematic SLVA Model can help to better guide both vocabulary instruction and acquisition.

Vocabulary tests including any of these three major components of lexical knowledge-the aspects of lexical quality, quantity and degree of organization-can help us to more clearly evaluate and understand a leamer's overall first or second language vocabulary development. When doing so, some use Chapelle's (1994) model of context, vocabulary ability and cognitive versus metacognitive processes, while others use Nation's (2001) simpler model of form, meaning and use (as shown in Table 2, which clarifies each of these respective major aspects of vocabulary knowledge needing better instruction and assessment). Schmitt (2000) has also chosen to use Nation's (1990) components of word knowledge approach as his basis for discussing vocabulary. This essay will also use his dual framework for building a clearer taxonomy of SLVA teaching and testing, the dual aspects involved in knowing a word which are 
1) Meaning and its mental organization, and 2) Word form and grammatical knowledge.

It describes three evaluative instruments used together systematically in an attempt to help better triangulate, understand and describe these three major aspects of SLVA among Japanese college students.

\section{The Case Study Context: Participants and Procedures:}

Research Questions--This study aimed to provide answers to these research questions:

1) What vocabulary learning strategies (VLS) do Japanese college students use in learning more advanced English academic vocabulary (EAP), that are generally recognized as being needed for success in further academic study in English?

2) How may VLS identified in previous studies be more clearly classified and extended by research, and more effectively practiced and learned by foreign language students?

3) Can a set of the most essential phases of vocabulary learning be taught logically, simply and systematically so as to affect positive change in learners' VLS awareness and habits?

4) Does a particular approach to or combination of strategies in academic vocabulary learning (EAP/ESP) help to predict participants' degree of success on English proficiency or reading level exams, indicating a greater possibility of future success in study or work abroad in English-speaking countries? Study Context--The context for this study was an engineering university in northem Kyushu,

Japan. All students were freshmen. Of the 60 Engineering Freshmen polled in this study, 55 were males. Engineering students were whole class samples from three general education Oral Conversation classes of about twenty students each. Only those present on the day of the survey were included.

Methods Used--Procedures used to collect data to answer these research questions were as follows. Students were exposed to eight of the most essential kinds of Vocabulary Learning Strategies (VLS) outlined in an easily understood, user-friendly Depth of Lexical Processing Taxonomy (Table 2), which was explained bilingually. Having a practical and user-friendly Depth of Lexical Processing Taxonomy available (such as that shown in Table 2) can help both language instructors and learners to better monitor vocabulary developinent, so that they can be given more specific vocabulary learning strategies (VLS) instruction and practice in weak or neglected areas. 
During the first semester students were given standardized reading tests (Gates-McGinite, Form C), and exposed to using a Dual Assessment Vocabulary Instructor-Evaluator Scale (See in Table 3, or Author, 2002a, and see 2003a \& 2004b, for its analysis). This VKS was informed by both Zimmerman's (1997) and Wesche \& Paribakht's (1996) models, although its design is rather unique, being explained bilingually and easier to assess and understand on the part of Japanese teachers and students. During the second semester a bilingual VLS Survey was prepared adopted from Schmitt (1997), and given to each of these students.

Students were also interviewed as to the specific VLS they used when meeting unknown EAP words, and the types of dictionaries they were using, with respective functions for any that were computerized. All of this information was used in two ways: 1) to make class profiles or group overviews of vocabulary level averages and totals regarding VLS use; and 2) to create individual reading profiles or portraits of each learner's VLS, vocabulary, comprehension and expected reading grade level. Finally, at the end of the school year, an Approach to Vocabulary Learning Questionnaire (AVQ) was given, modeled after ones used in previous studies by Sanaoui $(1992,1995)$, and Lessard-Clouston (1998; 2000). Participants are asked to list ten new terms or expressions they learned in the course and to try to remember where or how they learned them.

Also data was gathered regarding the five areas stressed as significant in Sanaoui's $(1992,1995)$ research. A survey designed for this study was then compared with Sanaoui's five aspects of difference between students who were mone structured and skilled in learning vocabulary versus those that were unstructured and hence less skilled. This was to help ensure that the most important VLS were included in our survey. It had 35 strategies.

Schmitt and Schmitt's (1993, pp. 28-30) initial learning strategies were first compared with a survey of VLS prepared for this study to see possible overlap. They had found fourteen ways 600 Japanese students of different age groups tried to learn new English words. These were grouped into the six categories of 1) Using reference materials (monolingual/ bilingual dictionaries); 2) Asking others for help; 3) Word analysis from available data; 4) Creating a system to analyze words; 5) Using knowledge of other languages to guess; and 6) Avoiding or skipping the word. They also found that Japanese students they observed used twenty-eight strategies for remembering new word meanings, which could be grouped under these ten categories: 1) Repetition; 2) Studying word parts, spelling, sounds, or grammatical functions; 3) Using study aids; 4) Continuation; 5) Physical and/or verbal actions; 6) Using or paraphrasing 
words; 7) Creating an association system; 8) Working with others; 9) Linking auditory cues or visual images to serve as prompts; and 10) Using knowledge of other languages to help remember L2 word meanings. The survey was then revised and translated once again to assure maximum possible understanding by Japanese college students taking it. It was then given as described below. Any strategy used was weighted as 2.5 points (times 40 ?s $=100 \%$ ), to derive a percentage of total available strategies (VLS) used.

\section{Results:}

Survey results when given to 60 Japanese engineering students are shown in rear Table 1. Although an attempt was made to ask what type of interaction was preferred by these students when learning new words, few of them checked any answer other than learning alone, so this portion of the survey was scrapped. Options however were "I Prefer doing this: A. Alone, B. With partner/group, C. As a whole class with Teacher Input." Lack of variety or desire to learn new words outside of individualized isolation indicates that English education for most current Japanese college students appears to have given a severe lack of former experience and training in the beneficial effects of both learning from social interactive communication and cooperative learning.

Results obtained in this study of 60 Japanese college students' VLS are in general agreement with the findings of both Sanaoui $(1992,1995)$ and Kojic-Sabo and Lightbown's studies (1999) in the following ways. Just as Schmitt (1997) isolated 58 VLS used by various Japanese learners, this study found they reported using all 40 of the VLS listed in the survey, although three VLS were listed by $3 \%$ or less of the respondents, so they may not have been in actual use. These least used strategies need to be taught, it seems, since they have such great potential to help strengthen students' initial learning as well as longer term retention. They were 1) \#13, Archiving on a computer for later review or printing, 2) \#32, Drawing a picture to show real use, and 3) \#33, Using target words in a creative vocabulary story.

\section{Discussion:}

With regard to research question 1) Japanese college students tested generally use very few of the most essential vocabulary learning strategies VLS generally recognized as being needed for success in 
further academic study in English. On average these engineering students (at what is regarded as the best engineering college in Kyushu) used slightly less than half of the DLP Discovery Strategies 1-4, just $48.75 \%$, and only about one-fourth or $26 \%$ of DLP Consolidating Strategies 5-8.

With regard to research questions 2-4: 2) How may VLS identified in previous studies be more clearly. classified and extended by research, and more effectively practiced and learned by foreign language students, this two-part Depth of Lexical Processing Scale and 40-item VLS Survey have been offered and tested successfully. It helps to clearly identify individual learner strengths and weaknesses to better focus their vocabulary strategy training in the future. Table 4 (Depth of Lexical Processing Scale: Bilingual 8-Fold VLS Taxonomy) is used to instruct Japanese in how to effectively employ this Taxonomy of vocabulary learning steps, skills and strategies to build their TL vocabulary as rapidly as possible. Table 5 shows “Japanese College Students' Response to 8-Fold Depth of Lexical Processing Taxonomy and Revised Schmitt VLS Survey," showing Class Profiles of major VLS strategy types, if they were used or regarded as useful by these students.

3) A set of the most essential phases of vocabulary learning can be taught logically, simply and systematically by training students to use such a Depth of Lexical Processing Scale and Taxonomy so as to affect positive change in their VLS awareness and habits, enabling them to better monitor their own vocabulary study habits and progress.

4) Does a particular approach to or combination of strategies in academic vocabulary leaming (EAP/ESP) help to predict participants' degree of success on English proficiency or reading level exams, indicating a greater possibility of future success in study or work abroad in English-speaking countries, the following may be said. Participants' self-reported VLS data on both the survey and AVQ (Approach to Vocabulary Learning Questionnaire) were used to determine a learner's placement on a scale from unstructured, semi-structured, to structured. Although Lessard-Clouson (1998; 2000) used Sanaoui's five features to determine whether a learner was structured or unstructured, taking three distinct VLS as sufficient to call them "structured," these seemed to be insufficient and the first two items too broad and vague. Thus this study used a longer survey with eight categories or steps of lexical processing having thirty-five possible strategies (VLS). Then an Approach to Vocabulary Learning Questionnaire (AVQ in Appendix) was done with follow-up interviews about these eight areas of vocabulary learning, also asking students to list ten new words they had leamed, telling how they had studied and remembered them. Results of this study clearly supported Sanaoui's (1992, 1995) and Kojic-Sabo \& Lightbown's (1999) 
findings that more structured learners are also more effective in their vocabulary learning, as evidenced by consistently higher vocabulary levels shown by higher level VLS users.

\section{Conclusions:}

Although no one VLS is necessarily most effective for all learners, these eight lexical processing steps and skills are certainly essential to learning most new $\mathrm{TL}$ words and phrases. Strategies are means to achieving these skills, and these ways may differ. However, as Kojic-Sabo \& Lightbown's (1999, p. 19091) findings also make clear, "What is essential in enhancing students' lexical competence is to make them aware of all the possible ways vocabulary acquisition can be approached and, ultimately, to make them [more] responsible for their own learning."

When considering the all-important question of how language leamers can build up their TL vocabularies, EFL students, such as those classes studied here, need to be shown that a wide range of useful strategies can be used to more rapidly build up their TL vocabulary and comprehension skills. These may have greater benefits to some learners at certain times than at others. But all learners should be made more aware of this wide range of vocabulary learning strategies so that they can become more effective and independent language leamers as they develop greater flexibility in their response to unknown words.

Language learners and teachers need to combine as many of these suggested vocabulary learning guidelines, steps and strategies as possible to build up a strong vocabulary in their target language as quickly as possible, as many other studies besides those of this writer have shown (Kudo, 1999; LessandClouston, 1998, 2000; Nation, 2001; Segler et al, 2000). Since we learn by doing, only through disciplined, systematic training and regular practice can foreign language leamers adequately build up their TL vocabulary, namely by using it as actively and as often as possible.

\section{SLVA Pedagogical Implications and Recommendations for Teaching and Testing}

This article has proposed several evaluative and instructional tools and ways in which both L1 and L2 vocabulary assessment and instruction can be made more accessible and understandable by using them within a simple, yet all-encompassing model of second language vocabulary acquisition (SLVA). 
The trinity of user-friendly assessment tools presented within this holistic model of SLVA helps to show how all the major aspects of lexical acquisition must be considered when planning vocabulary teaching or research. It does provide a way in which the complex and various facets of second language vocabulary learning can actually be measured with instruments that are user-friendly, and which can be made understandable to students and teachers alike.

Good vocabulary tests, as Schmitt (2000: 171) characterizes them, are those that can give us a good amount and quality of vocabulary "knowledge information in a time-efficient and verifiable manner." The three tools discussed in this overview help to provide a more three-dimensional view of the development of vocabulary knowledge of new word forms, meanings and uses. Bottom line conclusions and vocabulary learning principles can now be proposed for further research. Pedagogical and research implications for Second Language Vocabulary Acquisition that flow from examining these assessment and instructional tools include the following major principles:

1. More rapid receptive vocabulary development can take place if groups of words with similar meanings are learned together and related by the Semantic Field Keyword Approach.

2. Better development of productive vocabulary requires activation, which may be helped by employing inethods such as pushed output generation using groups of semantically related words together.

3. The more thoroughly learners process new TL words, phrases and language patterns through each of these major phases of lexical processing, the more fully they will be learned in their three major aspects of form, use and meaning. This is turn can help bring about more complete and effective SLVA in both quantitative terms/size as well as qualitatively in terms of degree of lexical organization and richness. In other words, the quality of a language learner's vocabulary learning seems to depend heavily on these factors: a) Degree or depth of lexical processing, b) Number and quality of vocabulary learning strategies used, and c) Degree of organization of both L1 and L2 mental lexicons (how well-structured they are).

In addition, logical extensions from each of these major phases of lexical processing include:

The degree of exposure to, training and practice in using enough of these essential phases and strategies of vocabulary leaming determines to a large extent the rate, quantity and quality of one's Second Language Vocabulary Acquisition. More focused attention and assessment given to mastering the most crucial highfrequency vocabulary as early as possible will result in better text coverage and more effective incidental 
learning from context as well. More rapid access to target terms, which bilingualized and computerized dictionaries can help to provide, will help to confirm or correct learners' guesses earlier, enabling quicker learning time. Using more disciplined physical or electronic recording practices to archive new terms can help to fix them more rapidly in learners' minds, as can the use of multimedia to help provide memorable illustrations, cues, links or hooks to fix them in short-term memory. Better analysis and activation are required to improve leamers' understanding of word origins, parts of speech, and proper patterns of appropriate use. One's degree of activation largely determines how well one's productive vocabulary develops. Quality of review techniques or media functions used by a learner largely determine both their speed and percentage of retrieval of new target terms and language forms. Reaction and retrieval times can be improved by giving more recent and frequent encounters with target terms, helping to reactivate them by building further memory traces. Along with recycling and review techniques to improve recognition and prediction skills, reassessing of learning must be done regularly with frequent individual feedback to maximize motivation and acquisition.

I see a pedagogically useful SLVA model as having four possible modes for instruction or study, each of which need to be tested and compared with more $L 1$ and L2 comparative research, to arrive at the most ideal combination of strategies. Options for teaching and modes for Second Language Vocabulary Acquisition (SLVA) and instruction that now exist seem to include these possibilities:

1) Non-Assisted: On your own guessing from context only (No dictionary support), which characterizes Rapaport and Kibby's (2001) Contextual Vocabulary Acquisition scientific model;

2) Human-Aided (Non-Technical): Asking people or Accessing book dictionaries allowed. This area is divisible into two kinds of studies, those focusing on investigating which types of negotiated input and output best facilitate vocabulary acquisition, as well as studies using book dictionaries;

3) Multimedia CALL Only: with no human assistance present, but perhaps available online if synchronous communication is available via Internet-mediated, Network-based Language Teaching; and finally 4) Integrated ICALL with Human Assistance Present: Using ICALL in language classrooms as just one tool for developing all four communication skills, also integrating use of all types of media. Such a healthy integration of both human- and machine-assisted language instruction and communication using multimedia and all the available innovative technologies of Intelligent CALL, including Internet- 
mediation, digitized media and four-skills integration as connection speeds become more instantaneous (close to real time) and devices more portable will all help to normalize CALL to its ultimate ideal so that it becomes a part of more students' daily routines and educational life. Each of these modes stands in need of further testing and comparison. The above overview of new and existing ways of testing various aspects of lexical knowledge, study and use can help to generate many fertile ideas for improving our teaching, testing and research about various important components of vocabulary development.

The evaluative benefit of these three recently designed lexical assessment instruments is that they can help us to better measure and understand various aspects of vocabulary learning and study, including the degree of organization of learners' mental lexicons and level of strategy use at each particular phase of lexical processing, especially when the broader Depth of Lexical Processing Scale and Vocabulary Learning Strategies Taxonomy are used together with the more specific DAVIE VKS. When combined, these vocabulary assessment tools can be used to measure both major aspects of receptive and productive vocabulary knowledge as they are developing, and size as well as depth regarding any particular set of TL vocabulary terms.

Each of these evaluative instruments can help to guide both instruction and assessment at the individual learner level, as well as being easy to average to obtain overall percentages of baseline and progress levels in any of their categories for any class of students. Such instruments can help us to create and contribute more detailed diagnosis and more accurate views of learners within "Individual Profiles" or "Class Profiles," to help improve the focus of vocabulary instruction through the improved individualization and item analysis which they can help make possible. Better assessment means teachers can focus valuable time and resources more efficiently on generally unknown words, or on essential vocabulary learning strategies and phases of lexical processing in which most learners yet lack proficiency. Using all three of these tools together can provide us with a sort of assessment triangulation or verification, as well as give a more three-dimensional view of each learner's vocabulary knowledge (including L1 vs. L2, receptive vs. productive, and size vs. quality), depth of lexical processing used, and number and organizational level of VLS used by each student. Most importantly from a learner's perspective, all three of these testing and teaching tools serve not only for word assessment, but also to help guide students in achieving better word attack and comprehension skills. They can thus serve to provide a better three- 
pronged plan to both language teachers and learners for improving not only their basic TL word attack skills, but also their vocabulary leaming strategy skills, including self-monitoring of their own vocabulary and language study progress that comes with improved consciousness about essential phases of lexical processing and organization.

\section{References}

Author. (1996). Developing and testing vocabulary training methods and materials for Japanese college students studying English as a foreign language. Ed. D. Dissertation on file with Pensacola Christian College, Pensacola, FL. Also available either from ERIC Center for Applied Linguistics via fax to (202)-429-9292; or from UMI Dissertation Services, 30 No. Zeeb Rd., PO Box 1346, Ann Arbor, MI 48106-1346. (http.//www.umi.com).

. (1997a). Maximizing vocabulary acquisition: Recommendations for improving English vocabulary learning for foreign language learners. KASELE Kiyo 25: 101-111.

. (1997b). Summary of "Developing and testing vocabulary training methods and materials for Japanese college students studying English as a foreign language." Annual Review of English Learning and Teaching, No 2, JACET Kyushu-Okinawa Chapter. (9/30/97: 15-36). . (1998). Suggestions for improving ESL/EFL vocabulary instruction. Seinan JoGakuin Kiyo 45. (2002a). Assessing the potential of computerized bilingual dictionaries for maximizing English vocabulary learning in Japan. In Lewis, P. N. D. (Ed.), The changing face of CALL: A Japanese perspective. Amsterdam: Swets \& Zeitlinger.

. (2002b). Testing vocabulary levels in Japan. The Japanese Learner. Oxford: Oxford

University. Part I (pp. 15-21).

. (2002c). Enhancing students' English reading and vocabulary skills using CALL innovations:

JALT CALL 2002 National Conference Presentation. Seinan Women's University, Junior College Kiyo, No. 49.

. (2002d). Comparing translation software and OCR reading pens. On Swanson, M., McMurray, C., \& Lane, K. (Eds.), Pan-Asian Conference 3 at $27^{\text {th }}$ International Conference of JALT National Conference Proceedings CD. Kitakyushu, JAPAN. Pages 745-755. 
. (2003a). Testing vocabulary levels in Japan, Part II. The Japanese Learner, No. 29, (March), pp. 15-20. Oxford: Oxford University.

. (2003b). Improving access to target vocabulary using computerized bilingual dictionaries.

ReCALL 14 (2), pp. 293-312. Cambridge: Cambridge University Press.

(2003c). Using computerized bilingual dictionaries to help maximize English vocabulary

learning at Japanese colleges. CALICO Journal, 105-129, (September Issue).

. (2003d). Using CALL innovations to enhance students' English reading and vocabulary skills. In

P. N. D. Lewis, C. Imai, \& K. Kitao (Eds.), Local Decisions, Global Effects: The Proceedings of JALT CALL 2002, 121-128.

(2004b). Designing and testing the use of a Dual Assessment Vocabulary Instructor-

Evaluator for teaching essential verbs and adjectives to Asian students. Forthcoming Orio Aishin Keizai Kiyo.

(2004c). Improving cognitive, linguistic and computational processing of new vocabulary using an online Semantic Field Keyword Approach. JALT CALL SIG, CALLing Japan. (7-20). (2005a). Finding better ways to learn vocabulary using a Depth of Lexical Processing Taxonomy: Maximizing SLVA by systematic use of CALL innovations and effective lexical strategies. (Forthcoming). CALICO Journal, 22, 1. (2005b). Surveying Foreign Language Learners' Use of Electronic Dictionaries. Seinan Women's University Kiyo \#9. . (2005c) Comparing receptive versus productive effectiveness of various dictionaries used at Japanese colleges. Forthcoming.

Chapelle, C. A. (1994). Are C-tests valid measures for L2 vocabulary research? Second Language Research 10, 157-187.

Cohen, A. D., and Aphek, E. (1981). Easifying second language learning. Studies in Second Language Acquisition, 3, 221-236.

Craik, F. I. M., \& Lockhart, R. (1972). Levels of Processing: A framework for memory research. Journal of Verbal Learning and Verbal Behavior II: 671-84.

Craik, F. I. M., \& Tulving, E. (1975). Depth of processing and the retention of words in episodic memory. 
Journal of Experimental Psychology 104: 268-84.

Ellis, N. (1995). Vocabulary acquisition: Psychological perspectives. The Language Teacher 19,2: 12-16.

Gates-MacGinite Reading Tests. (1976-Present). Chicago: Riverside Publishing.

Hatch, E., \& Brown, C. (1995). Vocabulary, Semantics and Language Education. Cambridge: Cambridge University Press.

Hsiao, C. \& Oxford, R. (2002). Comparing theories of language learning strategies: A confirmatory factor analysis. Modern Language Journal, 86, iii, 368-363.

Kojic-Sabo, I., \& Lightbown, P. M. (1999). Students' approaches to vocabulary learning and their relationship to success. Modern Language Learner, Vol. 83, No. ii, pp. 176-192.

Kudo, Y. (1999). L2 vocabulary learning strategies. (nflrc network 14, html document). Honolulu: University of Hawai'i, Second Language Teaching \& Curriculum Center. Retrieved from the World Wide Web: http://www,lll.hawaii.edu/nflrc/NetWorks/NW14/.

Lessard-Clouston, M. (1998). Vocabulary learning strategies for specialized vocabulary acquisition: A Case Study. Paper presented at the Annual Meeting of the Pacific Second Language Research Forum ( $3^{\text {rd }}$, Tokyo, Japan, March 26, 1998).

$\therefore$ (2000, March). Students' approaches to technical vocabulary learning in an academic context:

Relating strategies and success. Paper presented at the Annual Conference of the American Association for Applied Linguistics, Vancouver, British Columbia, Canada.

Meara, P. 1995. The importance of an early emphasis in L2 vocabulary. The Language Teacher 19, (2), 8-10.

Nation, I. S. P. (1990). Teaching and Learning Vocabulary. N.Y.: Newbury House. . (1994). (Ed.) New Ways in Teaching Vocabulary. Alexandria, VA. TESOL. . (2001). Learning vocabulary in another language. Cambridge: Cambridge University Press.

Nation, P., \& J. Newton. (1997). Teaching vocabulary. In Coady, J and T. Huckin. Second language Vocabulary acquisition: A rationale for pedagogy. Cambridge: CUP. 238-254.

Oxford, R. (1990). Language learning strategies: What every teacher should know. N.Y.: Newbury.

Pressley, M., Levin, J. R., \& Delaney, H. (1982). Mnemonic keyword method. Review of Educational Research, 52, 1, 61-91. 
Read, J. (2000). Assessing vocabulary. J. C. Alderson \& L. F. Bachman (Eds.), Cambridge Language Assessment Series. Cambridge: Cambridge University Press.

Richards, J. C. (1976). The role of vocabulary teaching. TESOL Quarterly 10, 77-89.

Sanaoui, R. (1992). Vocabulary learning and teaching in French as a second language classrooms. Unpublished doctoral dissertation, University of Toronto. (1995). Adult learner's approaches to learning vocabulary in second languages. Modern Language Journal. 79 (1): 15 - 28.

Schmitt, N.\& D. R. Schmitt. (1993). Identifying and assessing vocabulary learning strategies. Thai TESOL Bulletin; Vol. 5, No. 4, pp. 27-33, March 1993.

Schmitt, N. (1997). Vocabulary learning strategies. In Schmitt, N., \& McCarthy, M. (Eds.), Vocabulary: Description, Acquisition and Pedagogy. Cambridge: Cambridge University Press.

Segler, T., Pain, H., \& Sorace, A. (2001). Second Language Vocabulary Acquisition and Learning Strategies in ICALL Environments. Workshop on Computer Assisted Language Learning, AI-Ed 2001, San Antonio, TX.

Selinker, L. (1972). Interlanguage. IRAL: International Review of Applied Linguistics, (10), 3, 209-231.

Stoffer, T. K. (1995). Review of Practical Techniques for Language Teaching, (rev. ed.), M. Lewis and Hill, J., TESL-EJ, Volume 14 (R-5).

Tarone, E. (1977). Conscious communication strategies in interlanguage. In H. D. Brown, C. Yorio, \& R. Crymes (Eds.), On TESOL 1977 (pp. 194-203). WA, DC: TESOL. . (1980). Communication strategies, foreigner talk and repair. Language Learning, 30, 417-431.

Waring, R. (2002). Scales of vocabulary knowledge in second language vocabulary assessment. Kiyo, Notre Dame Seishin University: Studies in Foreign Languages and Literature 26 (1): 40-54. Wesche, M. and T. S. Paribakht. (1996). Assessing vocabulary knowledge: depth vs. breadth Canadian Modern Language Review. 53 (1): 13-40.

West, M. (1953). A General Service List (GSL) of English Words. London: Longman.

Zimmerman, C. (1997). Do reading and interactive vocabulary instruction make a difference? An empirical study. TESOL Quarterly. 31 (1): 121-40 
Table 1: 40-Item Vocabulary Learning Taxonomy Checklist: Organized by Phases of Lexical Processing, Learning Steps, Skills and Strategies

(Check each Strategy that you regularly use, telling which way of learning new words you find most helpful and enjoyable when using that strategy for learning new words or phrases. Count the total number of possible strategies used. Then multiply total \# $\times 2.5$ for a total possible VLS\% on this scale).

VLS.Score=

Reading Grade Level:

Student Name:

\section{DISCOVERY OF NEW WORD MEANINGS BY MAJOR STRATEGIES 1-4}

\section{1) Assessing (Pre-Test) \\ (Circle things you do to learn new words)}

$26 \%$ 1. Evaluate which words I know (VKS) 46\% 2. Guess unknown words or

$58 \%$ 3. Mark for Study $32 \%$ 4. If no need, Skip

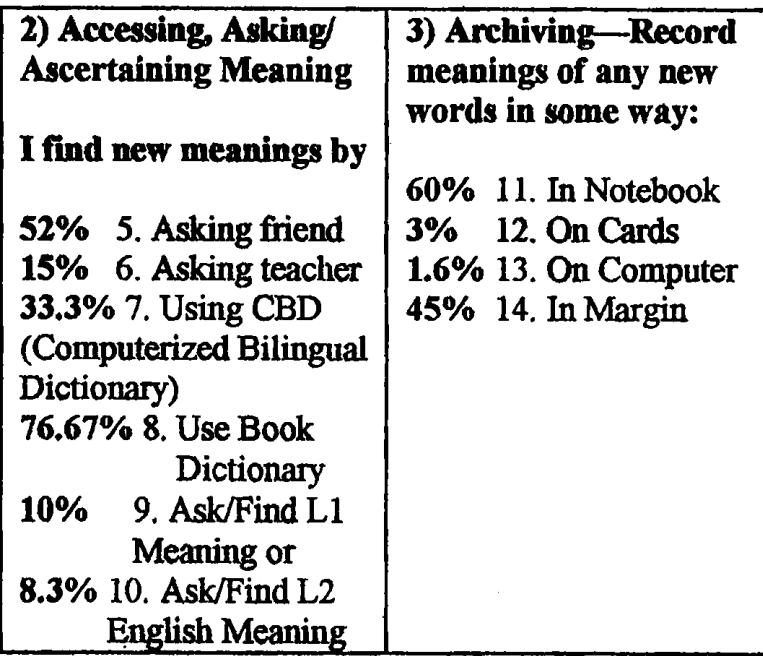

4) Analyzing-Divide word into parts by:

$28 \%$ 15. Base/Root Word

25\% 16. Beginning

8\% 17. Endings

$15 \%$ 18. Pronunciation

31.6\% 19. Grammar:

Use Parts of Speech

23.3\% 20. Use Word Origins

\section{CONSOLIDATING NEW WORD FORMS \& MEANINGS BY MAJOR VLS}

\begin{tabular}{|c|c|c|c|}
\hline $\begin{array}{l}\text { 4) Associating- } \\
\text { I organize new words: } \\
26.7 \% \text { 21. by Alphabet } \\
28.3 \% \text { 22. by Grammar } \\
38.3 \% \text { 23. I Learn } \\
\text { Related Groups under } \\
\text { simple, known } \\
\text { Keywords (Semantic } \\
\text { Field Way) or with } \\
\text { Concept Maps } \\
\text { I Don't Organize }\end{array}$ & 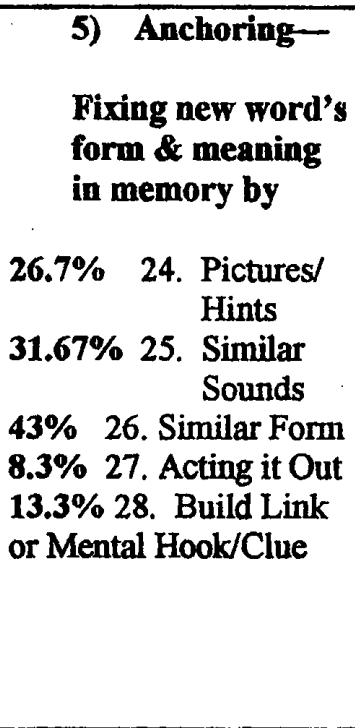 & $\begin{array}{l}\text { 6) Activating } \\
\text { Do you Use a new } \\
\text { word soon in your } \\
\text { Expression either: } \\
\\
\text { 31.7\% 29. In Speaking } \\
\mathbf{7 8 . 3 \%} 30 \text {. In Writing } \\
\mathbf{6 . 7 \%} 31 . \text { In a Play/Skit } \\
\mathbf{1 . 7 \%} 32 . \text { Draw a } \\
\text { Picture show real use } \\
3.33 \% 33 \text {. Use in a } \\
\text { Creative Vocabulary } \\
\text { Story }\end{array}$ & $\begin{array}{l}\text { 8) Reassessing, } \\
\text { Reviewing, and } \\
\text { Recycling (Post-Test) } \\
20 \% \text { 34. Study regularly } \\
33.3 \% \text { 35. Review } \\
\text { card/notes } \\
\mathbf{1 1 . 7 \%} 36 . \text { Reuse actively } \\
30 \% 37 . \text { Review by Lists } \\
\text { Recognizing Meanings } \\
\mathbf{2 1 . 6 7 \%} 38 \text {. Recall new } \\
\text { words from Memory } \\
\text { Links } \\
\text { 10\% 39. Reproduce } \\
\text { Story or Learned } \\
\text { Sentences } \\
\text { 15\% 40. Use in New } \\
\text { Contexts }\end{array}$ \\
\hline
\end{tabular}

LIST ANY OTHER STRATEGIES-Ways you try to discover or remember new words: 
Table 2: Depth of Lexical Processing Scale: Essential Vocabulary Learning Phases

An 8, 10, or 12-Part Depth of Lexical Processing Scale may be used. To more systematically assess students' TL vocabulary learning, allot 10 points for each of the first ten stages used (10 Stages $x 10$ points each $=100 \%$.) Fully Processed Target Language Vocabulary are those terms that have been thoroughly processed through each of these stages, now being at Stages 11 and/12. Teachers may use this Taxonomy as a Cyclical Continuum to help them better teach and assess each learner's "Depth of Lexical Processing." Students use 8-fold scale, teachers use 10-fold scale to guide instruction, researchers may use 12-phase scale to examine lexical processing in greater depth and detail.

\begin{tabular}{|c|c|c|c|c|c|c|c|c|}
\hline PHASE: & 1 & 2 & 3 & 4 & 5 & 6 & 7 & 8 \\
\hline $\begin{array}{c}\text { TL } \\
\text { Word }\end{array}$ & $\begin{array}{l}\text { Attend- } \\
\text { Assess }\end{array}$ & Access & Archive & Analyze & Anchor & Associate & Activate & $\begin{array}{l}\text { Review } \\
\text { Recycle }\end{array}$ \\
\hline 1 & & & & & & & & \\
\hline 2 & & & & & & & & \\
\hline 3 & & & & & & & & \\
\hline 9 & 10 & $\begin{array}{c}\text { GOAL: } \\
\text { Elaboration/ } \\
\text { Expansion }\end{array}$ & $\begin{array}{c}11 \\
\text { Automatic } \\
\text { Recognition }\end{array}$ & $\begin{array}{c}12 \\
\text { Predic- } \\
\text { tion }\end{array}$ & & $\begin{array}{l}\text { TLV "Fully } \\
\text { Acquired" } \\
\text { seems to be: }\end{array}$ & & \\
\hline $\begin{array}{l}\text { Reassess } \\
\text { Posttest }\end{array}$ & $\begin{array}{l}\text { Relearn } \\
\text { Remeet } \\
\text { Retelling }\end{array}$ & $\begin{array}{l}\text { of the L2 } \\
\text { Mental } \\
\text { Lexicon }\end{array}$ & $\begin{array}{c}\text { TLV meet } \\
\text { Richards' } 7 \\
\text { Criteria }\end{array}$ & $\begin{array}{l}\text { Building } \\
\text { Anticipa- } \\
\text { tory Set } \\
\text { Skills }\end{array}$ & & $\begin{array}{l}\text { Rapidly } \\
\text { Recognized/ } \\
\text { Productively } \\
\text { Activated }\end{array}$ & & \\
\hline & $\begin{array}{c}\text { Repeat } \\
\text { Cycle } \\
\text { Again }\end{array}$ & & $\begin{array}{c}\text { (1976, p. } \\
83)\end{array}$ & $\begin{array}{c}\text { Reason/ } \\
\text { Recall } \\
\text { Compre- } \\
\text { hension }\end{array}$ & & & & \\
\hline
\end{tabular}


Table 3: Three-Part Dual Assessment Vocabulary Instructor-Evaluator for Japanese Students A: Receptive Input Assessment Form (for Dual Assessment Vocabulary Instructor-Evaluator)

\begin{tabular}{|c|c|c|c|c|c|c|}
\hline$A(\%)$ & $B(\%)$ & $\mathrm{C}(\%)$ & $D(\%)$ & $\mathrm{E}(\%)$ & \# Words & Source \\
\hline $\begin{array}{l}\text { Recognition: } \\
\text { Know L1 } \\
\text { Japanese } \\
\text { Translation }\end{array}$ & $\begin{array}{l}\text { Recall: } \\
\text { Know L2 } \\
\text { English } \\
\text { Definition }\end{array}$ & $\begin{array}{l}\text { Self-Report: } \\
\text { Think I can } \\
\text { use word in } \\
\text { a Sentence }\end{array}$ & $\begin{array}{l}\text { Unclear: } \\
\text { Unsure but } \\
\text { can think of } \\
\text { phrase } \\
\text { where I have } \\
\text { read/heard it }\end{array}$ & $\begin{array}{l}\text { Unknown } \\
\text { Word: } \\
\text { No Idea at } \\
\text { all what it } \\
\text { means }\end{array}$ & $\begin{array}{l}\text { Word Token } \\
\text { or Family }\end{array}$ & $\begin{array}{l}\text { Modified } \\
\text { ICU } \\
\text { EAP List \# }\end{array}$ \\
\hline & & & & & $\begin{array}{l}\text { abandon } \\
\text { abbreviate } \\
\text { abide } \\
\text { ability } \\
\text { abnormal }\end{array}$ & $\begin{array}{l}1 \\
2 \\
3 \\
4 \\
5\end{array}$ \\
\hline
\end{tabular}

Date: / / Circle:

T1

Name:

Total Receptive Input\%

B: Productive Outcome Assessment (for Dual Assessment Vocabulary Instructor-Evaluator)

\begin{tabular}{|c|c|c|c|c|c|c|}
\hline$A(\%)$ & $B(\%)$ & $\mathrm{C}(\%)$ & $D(\%)$ & $E(\%)$ & \# Words & Source \\
\hline $\begin{array}{l}\text { Recognition: } \\
\text { Show L1 } \\
\text { Japanese } \\
\text { Translation } \\
\text { A ( } \%) \\
1 \text { Point }\end{array}$ & $\begin{array}{l}\text { Recall: } \\
\text { Show L2 } \\
\text { English } \\
\text { Definition } \\
\text { B ( \%) } \\
3 \text { Points }\end{array}$ & $\begin{array}{l}\text { Use/Record } \\
\text { Use this } \\
\text { Word in a } \\
\text { Sentence } \\
\text { C ( \%) } \\
4 \text { Clear or } \\
5 \text { Perfect }\end{array}$ & $\begin{array}{l}\text { Unclear: } \\
\text { Unsure, but } \\
\text { think I can } \\
\text { list a phrase } \\
\text { D ( \%) } \\
1 \text { Point }\end{array}$ & $\begin{array}{l}\text { Unknown } \\
\text { Word: } \\
\text { No Idea of } \\
\text { meaning } \\
\text { E ( \%) } \\
\text { No Points }\end{array}$ & $\begin{array}{l}\text { Word Token } \\
\text { or Family }\end{array}$ & $\begin{array}{l}\text { Modified } \\
\text { Intl. } \\
\text { Christian U. } \\
\text { EAP List: } \\
\text { JACET '92 } \\
\text { Mizoguchi, } \\
\text { et al. study }\end{array}$ \\
\hline & & & & & $\begin{array}{l}\text { abandon } \\
\text { abbreviate } \\
\text { abide } \\
\text { ability } \\
\text { abnormal }\end{array}$ & $\begin{array}{l}1 \\
2 \\
3 \\
4 \\
5\end{array}$ \\
\hline
\end{tabular}

C: Verification Procedure for Dual Assessment Vocabulary Instructor-Evaluator Responses

\begin{tabular}{|c|c|c|c|c|c|}
\hline $\begin{array}{l}\text { EAP/ESP } \\
\text { Word Token } \\
\text { or } \\
\text { Family }\end{array}$ & $\begin{array}{c}\text { Category A } \\
\text { Know L1 } \\
\text { (Japanese) } \\
\text { Translation } \\
\text { Self- } \\
\text { \% report } \\
\text { _\% Actual }\end{array}$ & $\begin{array}{c}\text { Category B } \\
\text { Know L2 } \\
\text { (English) } \\
\text { Definition } \\
\text { Self- } \\
\text { \% report } \\
\text { \%\% Actual }\end{array}$ & $\begin{array}{l}\text { Category C } \\
\text { Can Use } \\
\text { in Sentence } \\
\\
\text { Self- } \\
\text { \% report } \\
\text { \% \% Actual }\end{array}$ & $\begin{array}{c}\text { Category D } \\
\text { Unsure, but } \\
\text { think I can } \\
\text { use in phrase } \\
\text { Self- } \\
\text { \% report } \\
\text { _\% Actual }\end{array}$ & $\begin{array}{c}\text { Category } E \\
\text { Unknown } \\
\text { Word; No } \\
\text { Idea at all } \\
\\
\text { Self- } \\
\text { \% report } \\
\text { _\% Actual }\end{array}$ \\
\hline $\begin{array}{l}\text { Abandon } \\
\text { Abbreviate } \\
\text { Abide } \\
\text { Ability } \\
\text { Abnormal }\end{array}$ & & & & & \\
\hline
\end{tabular}


Table 4: Depth of Lexical Processing Scale:

A. Bilingual 8-Fold VLS Taxonomy

(Showing How to Use this Taxonomy of Vocabulary Learning Steps, Skills and Strategies)

\begin{tabular}{|c|c|c|c|c|c|c|c|}
\hline Phase 1 & Phase 2 & Phase 3 & Phase 4 & Phase 5 & Phase 6 & Phase 7 & Phase 8 \\
\hline $\begin{array}{l}\text { Assess: * } \\
\text { Make } \\
\text { Chances to } \\
\text { Learn TW }\end{array}$ & $\begin{array}{l}\text { Access: } \\
\text { Always } \\
\text { Look up, } \\
\text { Ask/Guess }\end{array}$ & $\begin{array}{l}\text { Archive } \\
\text { Keep } \\
\text { Records } \\
\text { Clearly }\end{array}$ & $\begin{array}{l}\text { Analyze } \\
\text { Separate } \\
\text { by Root \& } \\
\text { Parts }\end{array}$ & $\begin{array}{l}\text { Associate } \\
\text { Group } \\
\text { under a } \\
\text { Keyword }\end{array}$ & $\begin{array}{l}\text { Activate } \\
\text { Always } \\
\text { Practice } \\
\text { Using }\end{array}$ & $\begin{array}{l}\text { Anchor } \\
\text { Fix with } \\
\text { Memory } \\
\text { Tricks }\end{array}$ & $\begin{array}{l}\text { Reassess } \\
\text { Review } \\
\text { (Studyl) } \\
\text { Recycle } \\
\text { (Re-use) }\end{array}$ \\
\hline $\begin{array}{l}\text { Attend to } \\
\text { and Check } \\
\text { How Well } \\
\text { Its Known }\end{array}$ & $\begin{array}{l}\text { Connect to } \\
\text { Its Form, } \\
\text { Meaning, } \\
\text { and Use }\end{array}$ & $\begin{array}{l}\text { Record It } \\
{ }^{*} \mathrm{TW}= \\
\text { Target } \\
\text { Words }\end{array}$ & Divide It & $\begin{array}{l}\text { Organize } \\
\text { New } \\
\text { Target } \\
\text { Words }\end{array}$ & $\begin{array}{l}\text { Produce } \\
\text { Express }\end{array}$ & $\begin{array}{l}\text { Fix/Hook } \\
\text { by Audio- } \\
\text { Visual } \\
\text { Cues/Hints }\end{array}$ & $\begin{array}{l}\text { Repeat, } \\
\text { Re-meet, } \\
\text { Recheck } \\
\text { Regularly }\end{array}$ \\
\hline
\end{tabular}

\section{B. Lexical Processing Phases in Japanese}

\begin{tabular}{|c|c|c|c|c|c|c|c|}
\hline 評価 & 接近 & 記録 & 分離 & 整える & $\begin{array}{l}\text { 活動的 } \\
\text { に使う }\end{array}$ & 定着する & $\begin{array}{l}\text { 再評価 } \\
\text { 復習 }\end{array}$ \\
\hline A Mark & $\mathrm{ABBD}^{* * *}$ & & & & & A Draw & A Alone \\
\hline Unknown & B CBD & & & & & Picture & using \\
\hline Words & C MBD & & & & & B Think of & Cards \\
\hline B Make & $\mathrm{DCMD}$ & & & & & similar & B With \\
\hline Chances & (CBD- & & & & & sounding & Partner \\
\hline to Learn & $\mathrm{CMD}$ & & & & & word & C Class \\
\hline C Do VKS & Combo & & & & & C Act out & Archives \\
\hline & exists) & & & & & verbs & Files/Lists \\
\hline
\end{tabular}

*VLS=Vocabulary Learning Strategies; *BBD=Bilingual Book Dictionary; $\mathrm{CBD}=$ Computerized Bilingual Dictionary; $\mathrm{MBD}=$ Monolingual; Book Dictionary; $\mathrm{CMD}=$ Computerized Monolingual Dictionary 


\section{Explanation of Depth of Lexical Processing Scale and Survey Checklist:}

A. Initial Discovery or Learning Strategies (Use as Vocabulary Learning Checklist with students)

\begin{tabular}{|c|c|c|c|}
\hline $\begin{array}{l}\text { 1) Attend to New } \\
\text { Words \& Assess them }\end{array}$ & 2) Accessing- & 3) Archiving- & 4) Analyzing- \\
\hline Use __ Useful & Use _ Useful & Use _ Useful & Use Useful \\
\hline $\begin{array}{l}\text { Assess own Vocabulary } \\
\text { Level by VK Scales; } \\
\text { Headwords or Standard } \\
\text { Reading Pre-Tests } \\
\end{array}$ & $\begin{array}{l}\text { MEANING-FOCUSED } \\
\text { Accessing Definitions: } \\
\text { L1/L2; L1 \& L2 (Rapid } \\
\text { Access/Recall functions) }\end{array}$ & $\begin{array}{l}\text { Record Definitions with } \\
\text { Means to Recall/Study; } \\
\text { Keep VLS Notebooks; } \\
\text { (Rapid Recording Best) }\end{array}$ & $\begin{array}{l}\text { ROOTWORD- } \\
\text { CENTERED } \\
\text { Word Analysis of Base, } \\
\text { Affixes/Suffixes } \\
\end{array}$ \\
\hline $\begin{array}{l}\text { Highlight or Show List } \\
\text { Pre-teach; Use List; }\end{array}$ & $\begin{array}{l}\text { Various glossing types; } \\
\text { Teacher Defining pre- } \\
\text { instruction or during; } \\
\text { Book Dictionary } \\
\text { Lookup or Electronic }\end{array}$ & $\begin{array}{l}\text { Quickionary Pens with } \\
\text { OCR/CBDs=Computer } \\
\text { Bilingual Dictionaries }\end{array}$ & $\begin{array}{l}\text { Word Origins/Grammar; } \\
\text { Noting Context \& } \\
\text { Meaning while reading }\end{array}$ \\
\hline
\end{tabular}

B. Studying and Remembering or Consolidating Strategies

\begin{tabular}{|c|c|c|c|}
\hline $\begin{array}{l}\text { 5) Associating- } \\
\text { by Semantic Field } \\
\text { Keyword Approach= } \\
\text { Categorizing by Related } \\
\text { Classes by Keywords }\end{array}$ & $\begin{array}{l}\text { 6) Anchoring- } \\
\text { in one's memory (ST) } \\
\text { until it becomes fixed in } \\
\text { Long-Term Memory. } \\
\text { Use Mnemonic Devices }\end{array}$ & $\begin{array}{l}\text { 7) Activating- } \\
\text { USE-FOCUSED } \\
\text { (New Words/Phrases } \\
\text { Activated by Productive, } \\
\text { Expressive Use. }\end{array}$ & $\begin{array}{l}\text { 8) Reassessing, } \\
\text { Reviewing and } \\
\text { Recycling-Exercises: } \\
\text { Measure Vocabulary } \\
\text { Growth/ Change by } \\
\text { Similar Post-Test also to } \\
\text { Motivate attention/warn }\end{array}$ \\
\hline Use__ Useful__ & Use _ Useful __ & Useful _ & Use _ Useful _ \\
\hline
\end{tabular}


Table 5: Japanese College Students' Response to 8-Fold Depth of Lexical Processing Taxonomy and Revised Schmitt VLS Survey: Showing Class Profiles of Major VLS Strategy Types

Group 1: $\mathbf{n = 1 9}$

Group 2: $n=10$

Group 3: $n=10$

Group 4: $n=14$

5 Females, 33

Total $\mathrm{N}=53$
(1 Female, 18 Males in Period 1 at XIT Engineering University)

(15 Males in Period 2 at XIT Engineering University)

(4 Females, 20 Males in Period 3 at XIT Engineering University)

(14 Female English majors at Women's Junior College)

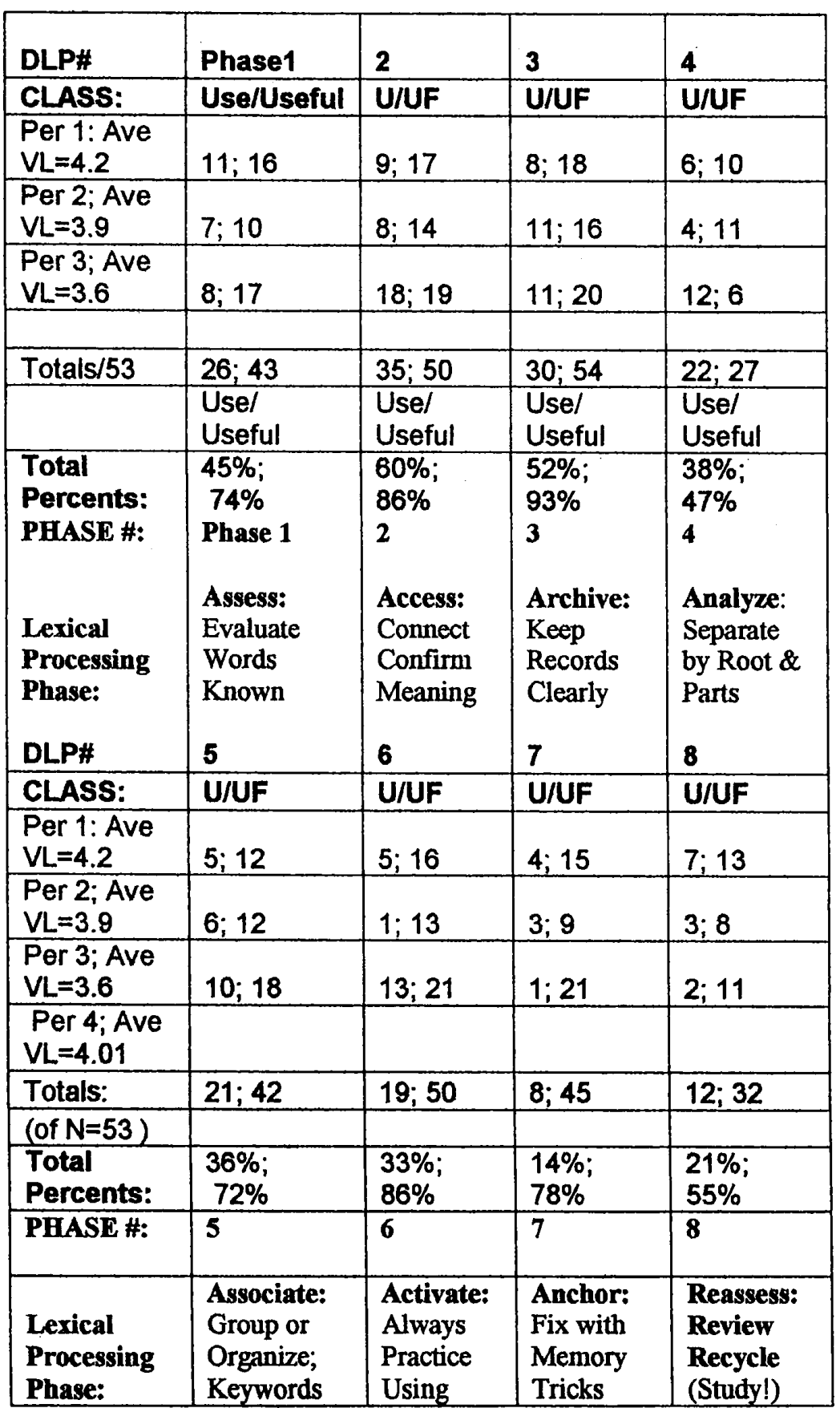

$\mathrm{U}=$ Use this Vocabulary Learning Strategy; UF=Find it Useful 
Table 6: Profile of Three Types of Approaches to Vocabulary Learning with Recommendations for Improved Teaching and Research about Lexical Processing Phases and Strategies $(\mathrm{L}=\mathrm{Learner})$

\begin{tabular}{|c|c|c|}
\hline A. Random, Unstructured L & B. Semi-Structured Learner & C. Systematic, Structured L \\
\hline $\begin{array}{l}\text { Uses } 3 \text { or less DLP steps } \\
\text { randomly \& inconsistently. }\end{array}$ & Uses 4-5 DLP steps consistently. & $\begin{array}{l}\text { Uses 6-8 DLP steps/phases } \\
\text { consistently }\end{array}$ \\
\hline $\begin{array}{l}\text { No particular approach or pattern } \\
\text { adopted in VLS use }\end{array}$ & Mainly just Discovery VLS used & $\begin{array}{l}\text { Uses both Discovery \& } \\
\text { Consolidating VLS together }\end{array}$ \\
\hline $\begin{array}{l}\text { Tends to shy away from using } \\
\text { new TL terms } \\
\text { Reluctant/Unwilling to try }\end{array}$ & $\begin{array}{l}\text { Will use if guided or pushed to } \\
\text { produce output; } \\
\text { Involuntary/Directed }\end{array}$ & $\begin{array}{l}\text { Try to incorporate new TL terms } \\
\text { via active use in own personal } \\
\text { expressions }\end{array}$ \\
\hline Haphazard, Disorganized & Semi-Organized; Simple & Well-Organized; Complex \\
\hline Lack LL Motivation & $\begin{array}{l}\text { Most have only ST Instrumental } \\
\text { Motivation; "Juist get thru the } \\
\text { course." }\end{array}$ & $\begin{array}{l}\text { Have both Integrative and } \\
\text { Instrumental Motivations. May } \\
\text { use SFKA Method. }\end{array}$ \\
\hline $\begin{array}{l}\text { Often bring no dictionary. } \\
\text { Won't try Monolingual Learner's } \\
\text { or CB Dictionary }\end{array}$ & $\begin{array}{l}\text { Tend to use CBDs, but only with } \\
\text { limited functions. * }\end{array}$ & $\begin{array}{l}\text { Tend to use CBDs with } \\
\text { Systematic, Multi-functional } \\
\text { approach. }\end{array}$ \\
\hline $\begin{array}{l}\text { Little or no vocabulary study } \\
\text { outside of class }\end{array}$ & $\begin{array}{l}\text { Some vocabulary study outside } \\
\text { of class, but limited actual use }\end{array}$ & $\begin{array}{l}\text { Tend to use Online Translation } \\
\text { Dictionaries; Tend to use } \\
\text { Advanced Learners' } \\
\text { Monolingual Dictionaries } \\
\text { (Book/CD). Tend to Monitor \& } \\
\text { Check on their own VL Progress. } \\
\text { Tend to Ask \& Interact socially } \\
\text { about new TLV. } \\
\text { Try to Incorporate new TL via } \\
\text { Active Expressive Use. }\end{array}$ \\
\hline
\end{tabular}

